\title{
Promotive effects of resistant maltodextrin on apparent absorption of calcium, magnesium, iron and zinc in rats
}

\author{
Shoko Miyazato $\cdot$ Chie Nakagawa $\cdot$ Yuka Kishimoto • \\ Hiroyuki Tagami $\cdot$ Hiroshi Hara
}

Received: 15 May 2009/Accepted: 29 September 2009/Published online: 24 November 2009

(C) The Author(s) 2009. This article is published with open access at Springerlink.com

\begin{abstract}
Background It has been reported that low-viscous and fermentable dietary fiber and nondigestible oligosaccharides enhance mineral absorption. Resistant maltodextrin, nonviscous, fermentable and soluble source of dietary fiber, has several physiological functions. However, influence of resistant maltodextrin on mineral absorption is unclear.

Aim of the study We conducted balance studies in rats to investigate effects of resistant maltodextrin and hydrogenated resistant maltodextrin on apparent mineral absorption. Methods In experiment 1 (Exp. 1), 40 rats were fed test diets based on AIN-93G with or without resistant maltodextrin or hydrogenated resistant maltodextrin for 2 weeks. In experiment 2 (Exp. 2), 32 rats were cecectomized (CX) or sham-operated (Sham) and fed diets with or without hydrogenated resistant maltodextrin for 1 week.

Results In Exp. 1, ingestion of resistant maltodextrin and hydrogenated resistant maltodextrin dose-dependently enhanced apparent absorption rates of $\mathrm{Ca}, \mathrm{Mg}, \mathrm{Fe}$ and $\mathrm{Zn}$, and increased cecal fermentation with cecal expansion. In Exp. 2, the absorption rates of $\mathrm{Ca}$ and $\mathrm{Mg}$ were significantly enhanced by ingestion of hydrogenated resistant maltodextrin in Sham group but not in CX group. The promotion of $\mathrm{Fe}$ and $\mathrm{Zn}$ absorption was not affected by cecectomy.
\end{abstract}

S. Miyazato $(\bowtie) \cdot$ Y. Kishimoto $\cdot$ H. Tagami

Research Laboratory, Matsutani Chemical Industry Co., Ltd.,

5-3 Kita-Itami, Itami, Hyogo 664-8508, Japan

e-mail: shoko-miyazato@matsutani.co.jp

C. Nakagawa $\cdot$ H. Hara

Division of Applied Bioscience, Graduate School of Agriculture,

Hokkaido University, Kita-9, Nishi-9, Kita-ku,

Sapporo 060-8589, Japan
Conclusion Ingestion of resistant maltodextrin and hydrogenated resistant maltodextrin increased apparent $\mathrm{Ca}$ and $\mathrm{Mg}$ absorptions dependent on cecal fermentation, while other mechanisms may also be involved in promotion of apparent $\mathrm{Fe}$ and $\mathrm{Zn}$ absorption by resistant maltodextrin.

Keywords Resistant maltodextrin .

Hydrogenated resistant maltodextrin .

Apparent mineral absorption - Cecal fermentation .

Short-chain fatty acid

\section{Background}

It has been reported that fructo-oligosaccharides [16], guar gum hydrolysate [5] and lactulose [1] increase mineral absorption as food materials. Those studies revealed that intestinal fermentation has positive effects on mineral absorption. Similarly, resistant maltodextrin, nonviscous soluble dietary fiber, is readily fermentable in the large intestine [10], and it may have effect on mineral absorption likewise.

Resistant maltodextrin (RMD) is produced from starch by heat and enzymatic treatments [11], and contains a mixture of oligo- and poly-glucosides with a random distribution of glycosidic linkages of 1-2 and 1-3 in addition to 1-4 and 1-6, which makes itself resistant to digestive enzymes. Therefore, most part of RMD is nondigestible and reaches the large intestine. RMD is a nonviscous fermentable soluble source of dietary fiber with an average molecular weight of 2000. Hydrogenated resistant maltodextrin is obtained by hydrogenation of RMD to suppress browning. Both are highly safe [18] and low-caloric food ingredients [15]. There have been many beverage and food products worldwide, in which RMD was incorporated. 
Recently, it has been reported that RMD has physiological effects in human such as improvement of bowel movement [13], improvement of glucose tolerance [2], and attenuation of postprandial blood triglyceride elevation [7]. It was reported that RMD does not inhibit diffusion of metal ions in vitro [9]; however, effects of RMD in vivo on mineral absorption such as calcium, magnesium, zinc and iron, has not been investigated.

The purposes of this study were to examine effects of resistant maltodextrin and hydrogenated resistant maltodextrin on apparent mineral absorption in rats by balance studies, and association of the cecal fermentation with the effects by using the cecectomized rats.

\section{Materials and methods}

\section{Materials}

Resistant maltodextrin (Fibersol 2, referred as FS2) and hydrogenated resistant maltodextrin (Fibersol 2H, referred as FS2H) are products of Matsutani Chemical Industry Co., Ltd. (Hyogo, Japan). Dietary fiber content of FS2 and FS2H served for this study were 88 and $87 \%$, respectively, by AOAC Official Method 2001.03 [3].

\section{Experimental methods}

Experiment 1: effect of resistant maltodextrin on apparent mineral absorption in rats

Male Sprague-Dawley rats (Clea Japan Inc., Tokyo, Japan), 5 weeks old, were housed individually in wire- bottom cages so that feces were separated to collect. The cages were placed in a room with controlled temperature $\left(22 \pm 2{ }^{\circ} \mathrm{C}\right)$, relative humidity $(40-60 \%)$ and lighting (lights from 08:00 to 20:00) through the experiment. Rats were given free access to deionized water and powdered semi-purified diet based on AIN-93G for 5 days to acclimatize, and were divided into 5 groups of 8 rats in a randomized block design based on body weight, followed by free access to the test diets shown in Table 1 for 2 weeks. Water and diets were offered ad libitum. The test diets contained $3,316.7 \mathrm{mg}$ of calcium, $836 \mathrm{mg}$ of magnesium, $12.5 \mathrm{mg}$ of iron, and $8.9 \mathrm{mg}$ of zinc per $\mathrm{kg}$ diet. Basically, all diet contains $5 \%$ cellulose, insoluble dietary fiber, base on AIN-93G composition. Dietary fiber content of FS2 and FS2H, which were used for the experiment, were analyzed as 88 and $87 \%$, respectively. Thus, assumed soluble dietary fiber content of $1.5 \% \mathrm{FS} 2 /$ $\mathrm{FS} 2 \mathrm{H}$ diet and $3.0 \% \mathrm{FS} 2 / \mathrm{FS} 2 \mathrm{H}$ diet were about 13 and $16 \mathrm{~g}$ per $\mathrm{kg}$ diet, respectively.

Feces were collected from day 4-7 (first period) and day 11-14 (second period) to measure apparent absorption rates of calcium $(\mathrm{Ca})$, magnesium $(\mathrm{Mg})$, iron $(\mathrm{Fe})$ and zinc $(\mathrm{Zn})$. Fecal samples were dry-ashed by heating linearly to $550{ }^{\circ} \mathrm{C}$ for $6 \mathrm{~h}$ and kept at that temperature for $18 \mathrm{~h}$, and mineral concentrations were measured by atomic absorption spectrophotometry (Z-5310, Hitachi Ltd., Tokyo, Japan). Apparent absorption rate was calculated as follows;

$$
\begin{aligned}
& \text { Apparent absorption rate }(\%) \\
& =(\text { total mineral intake }- \text { fecal mineral excretion }) / \\
& \quad \text { total mineral intake } \times 100
\end{aligned}
$$

At the end of experiment, rats were exsanguinated under

\begin{tabular}{|c|c|c|c|c|c|}
\hline & $\mathrm{Ctr}$ & $1.5 \% \mathrm{FS} 2$ & $3 \% \mathrm{FS} 2$ & $1.5 \% \mathrm{FS} 2 \mathrm{H}$ & $3 \% \mathrm{FS} 2 \mathrm{H}$ \\
\hline Casein & 200 & 200 & 200 & 200 & 200 \\
\hline Dextrin & 449.486 & 434.486 & 419.486 & 434.486 & 419.486 \\
\hline Sucrose & 200 & 200 & 200 & 200 & 200 \\
\hline Fibersol2 & - & 15 & 30 & - & - \\
\hline Fibersol2H & - & - & - & 15 & 30 \\
\hline Soybean oil & 50 & 50 & 50 & 50 & 50 \\
\hline Cellulose & 50 & 50 & 50 & 50 & 50 \\
\hline Mineral mixture ${ }^{\mathrm{a}}$ & 35 & 35 & 35 & 35 & 35 \\
\hline Vitamin mixture $^{\mathrm{b}}$ & 10 & 10 & 10 & 10 & 10 \\
\hline L-Cystine & 3 & 3 & 3 & 3 & 3 \\
\hline Choline bitartrate & 2.5 & 2.5 & 2.5 & 2.5 & 2.5 \\
\hline tert-Butylhydroquinone & 0.014 & 0.014 & 0.014 & 0.014 & 0.014 \\
\hline
\end{tabular}
anesthesia with pentobarbital between 10:00 and 12:00

Table 1 Composition of test diets $(\mathrm{g} / \mathrm{kg})$

FS2 Resistant maltodextrin, $F S 2 H$ hydrogenated resistant maltodextrin

${ }^{\text {a }}$ The composition of mineral mixture was based on AIN-93G. It provided (mg/kg diet): Ca, 5,003; Mg, 506.7; Fe, 35 and Zn, 30.1

b The composition of vitamin mixture was based on AIN-93 
Table 2 Effect of experimental diets on food intake and body weight gain in rats fed test diets for 14 days (Exp. 1)

\begin{tabular}{lllllrr}
\hline & $\mathrm{Ctr}$ & $1.5 \% \mathrm{FS} 2$ & $3.0 \%$ FS2 & $1.5 \%$ FS2H & $3.0 \%$ FS2H & $P$ \\
\hline Food intake (g/14 days) & $290 \pm 9.45$ & $251 \pm 10.8$ & $262 \pm 9.82$ & $268 \pm 6.99$ & $257 \pm 8.75$ & 0.195 \\
Body weight gain (g/14 days) & $115 \pm 4.33$ & $98.3 \pm 6.73$ & $102 \pm 3.49$ & $106 \pm 4.29$ & $108 \pm 5.42$ & 0.053 \\
\hline
\end{tabular}

Values are mean $\pm \mathrm{SE}(n=8)$

FS2 Resistant maltodextrin, FS2H hydrogenated resistant maltodextrin

without fasting. Liver was removed after perfusion with saline from the portal vein, and weighed. Both end of the cecum was ligated, removed with their contents, and weighed. The contents were collected, and the cecal tissue was washed with saline and weighed. The wet weight of the contents was calculated by subtracting the tissue weight from the total weight. The cecal contents were homogenized with four volumes of deionized water. The $\mathrm{pH}$ values of these homogenates were measured with a semiconducting electrode (ISFET pH sensor 0010-15C, Horiba, Ltd., Kyoto, Japan). The organic acids in the cecal homogenate were measured by ion-exclusion chromatography method using high-performance liquid chromatography (Organic acid analyzing system, Shimadzu Corporation, Kyoto, Japan) as previously described [6]. The kidney was also removed and weighed. The liver and kidney were freeze-dried, dry-ashed, and concentrations of $\mathrm{Fe}$ in the liver and $\mathrm{Ca}$ in the kidney were measured by atomic absorption spectrophotometry as described above.

This study was approved by the Hokkaido University Animal Committee, and animals were maintained in accordance with the guidelines of the Hokkaido University for the care and use of laboratory animals.

Experiment 2: effect of resistant maltodextrin and cecectomy on apparent mineral absorption in rats

Acclimatized rats, 32 in number, the same as Exp. 1 were divided into two groups. One group of 16 rats was cecectomized (CX) and the other group was sham-operated (Sham) [5]. Following 4-day recovery period, both CX and Sham rats were divided into 2 subgroups of 8 , respectively, and given free access to either Ctr or 3\% FS2H diet shown in Table 1 for 1 week. Feces were collected from day 4 to 7 to measure apparent mineral absorption as described in Exp. 1.

\section{Statistical analyses}

Values are expressed as mean \pm SEM. The results of experiment 1 were analyzed by one-way ANOVA, and the results of experiment 2 were analyzed by two-way ANOVA, diet and cecectomy. The significance of differences between groups was evaluated by Tukey's HSD test.
Statistical software used was SPSS (Ver. 13.0J, SPSS Japan). Level of significance was taken as $5 \%$ or lower, two tailed.

\section{Results}

\section{Experiment 1}

Food intake and body weight gain were not different among five groups (Table 2). Fecal consistency was normal and neither diarrhea nor soft feces were observed. Apparent mineral absorption rates are shown in Table 3. During the first period, apparent absorption rates of $\mathrm{Ca}, \mathrm{Mg}$ and $\mathrm{Fe}$ were increased dose-dependently by ingestion of FS2 and FS2H, and apparent absorption rates in the all fiber groups were significantly higher compared to the $\mathrm{Ctr}$ group. Apparent absorption rates of $\mathrm{Fe}$ in the 3\% FS2 and $3 \% \mathrm{FS} 2 \mathrm{H}$ groups were 122 and $117 \%$ greater compared to the $\mathrm{Ctr}$ group, respectively. Apparent $\mathrm{Zn}$ absorption was enhanced by the ingestion of FS2 regardless of dietary levels, while ingestion of FS2H dose-dependently increased the rates (Table 3). During the second period, although $\mathrm{Zn}$ absorption was not significantly different among the groups, absorptions of other minerals were increased as the first period (Table 3).

Dried liver weight was not different among five groups, while $\mathrm{Fe}$ content in the liver was dose-dependently increased by ingestion of FS2 and FS2H, and Fe content in the 3\% FS2 and 3\% FS2H groups were greater compared with those in the Ctr group (Table 4). Wet weight and $\mathrm{Ca}$ content in the kidney were not different among the groups.

Wet weights of cecal contents and cecal tissue were dose-dependently increased by ingestion of FS2 and FS2H, and both values in the 3\% FS2 and 3\% FS2H groups were significantly higher than those in the Ctr group (Table 5). Cecal $\mathrm{pH}$ was decreased by the ingestion of FS2 and FS2H (Table 5). Pools of SCFA in the cecal contents were dosedependently increased by the ingestion of FS2 and FS2H. Increases in acetic and propionic acids were prominent, which reflected in total SCFA pool (Table 6). Amount of lactic acid in the cecum was not significantly different; however, succinic acid was increased dose-dependently by the ingestion of FS2H rather than FS2. Each apparent 
Table 3 Effect of test diet on apparent mineral absorptions in rats fed test diets for 7 days (1st period) and 14 days (2nd period) (Exp. 1)

\begin{tabular}{|c|c|c|c|c|c|c|}
\hline & Ctr & $1.5 \% \mathrm{FS} 2$ & $3.0 \% \mathrm{FS} 2$ & $1.5 \% \mathrm{FS} 2 \mathrm{H}$ & $3.0 \% \mathrm{FS} 2 \mathrm{H}$ & $P$ \\
\hline \multicolumn{7}{|c|}{ First period } \\
\hline $\mathrm{Ca}$ & $68.2 \pm 2.61 \mathrm{a}$ & $84.8 \pm 1.85 b$ & $89.0 \pm 1.89 b$ & $81.5 \pm 1.90 \mathrm{~b}$ & $86.2 \pm 1.58 b$ & $<0.001$ \\
\hline $\mathrm{Mg}$ & $70.3 \pm 1.47 \mathrm{a}$ & $82.5 \pm 1.94 b$ & $86.5 \pm 2.03 b$ & $79.5 \pm 2.38 b$ & $87.3 \pm 1.86 b$ & $<0.001$ \\
\hline $\mathrm{Fe}$ & $24.5 \pm 3.43 \mathrm{a}$ & $44.2 \pm 3.20 \mathrm{bc}$ & $54.4 \pm 4.03 \mathrm{c}$ & $40.7 \pm 3.18 b$ & $53.1 \pm 3.66 \mathrm{bc}$ & $<0.001$ \\
\hline $\mathrm{Zn}$ & $26.1 \pm 1.89 \mathrm{a}$ & $38.4 \pm 2.44 b c$ & $36.8 \pm 2.40 \mathrm{bc}$ & $33.0 \pm 1.85 \mathrm{ab}$ & $42.9 \pm 2.74 \mathrm{c}$ & $<0.001$ \\
\hline \multicolumn{7}{|c|}{ Second period } \\
\hline $\mathrm{Ca}$ & $66.3 \pm 2.41 \mathrm{a}$ & $78.2 \pm 1.92 b$ & $80.8 \pm 2.73 b$ & $77.5 \pm 1.96 \mathrm{~b}$ & $82.8 \pm 1.31 \mathrm{~b}$ & $<0.001$ \\
\hline $\mathrm{Mg}$ & $71.6 \pm 1.49 \mathrm{a}$ & $81.3 \pm 1.55 \mathrm{ab}$ & $83.7 \pm 1.51 \mathrm{c}$ & $77.3 \pm 0.66 \mathrm{~b}$ & $82.3 \pm 1.43 \mathrm{bc}$ & $<0.001$ \\
\hline $\mathrm{Fe}$ & $24.4 \pm 2.06 \mathrm{a}$ & $35.5 \pm 1.91 \mathrm{ab}$ & $43.4 \pm 3.61 \mathrm{~b}$ & $37.4 \pm 3.55 b$ & $44.6 \pm 2.14 \mathrm{~b}$ & $<0.001$ \\
\hline $\mathrm{Zn}$ & $27.5 \pm 1.19$ & $31.9 \pm 1.00$ & $33.3 \pm 2.60$ & $27.1 \pm 3.45$ & $33.6 \pm 2.51$ & 0.146 \\
\hline
\end{tabular}

Values are means $\pm \mathrm{SE}(n=8)$. Within a row, values not sharing a common letter are significantly different at $P<0.05$

FS2 Resistant maltodextrin, FS2H hydrogenated resistant maltodextrin

Table 4 Dried liver weight, and content and concentration of Fe in liver in rats fed test diets for 14 days (Exp. 1)

\begin{tabular}{lllllrr}
\hline & Ctr & $1.5 \%$ FS2 & $3.0 \%$ FS2 & $1.5 \%$ FS2H & $3.0 \%$ FS2H & $P$ \\
\hline Dried liver weight $(\mathrm{g})$ & $4.37 \pm 0.29$ & $3.90 \pm 0.25$ & $4.10 \pm 0.19$ & $3.99 \pm 0.09$ & $3.98 \pm 0.21$ & 0.58 \\
Fe content $(\mu \mathrm{mol} /$ liver $)$ & $5.14 \pm 0.40 \mathrm{a}$ & $6.00 \pm 0.81 \mathrm{ab}$ & $10.1 \pm 1.04 \mathrm{c}$ & $8.27 \pm 1.08 \mathrm{abc}$ & $8.78 \pm 0.71 \mathrm{bc}$ & $<0.01$ \\
Fe concentration $(\mu \mathrm{mol} / \mathrm{g}$ dry liver) & $1.18 \pm 0.08 \mathrm{a}$ & $1.57 \pm 0.21 \mathrm{ab}$ & $2.54 \pm 0.33 \mathrm{~b}$ & $2.09 \pm 0.30 \mathrm{ab}$ & $2.21 \pm 0.17 \mathrm{~b}$ & $<0.01$
\end{tabular}

Values are means $\pm \mathrm{SE}(n=8)$. Within a row, values not sharing a common letter are significantly different at $P<0.05$

FS2 Resistant maltodextrin, FS2H hydrogenated resistant maltodextrin

Table 5 Wet weights of the cecal contents and tissue, and cecal $\mathrm{pH}$ in rats fed test diets for 14 days (Exp. 1)

\begin{tabular}{lllllll}
\hline & Ctr & $1.5 \%$ FS2 & $3.0 \%$ FS2 & $1.5 \%$ FS2H & $3.0 \%$ FS2H & $P$ \\
\hline Cecal contents $(\mathrm{g})$ & $2.37 \pm 0.54 \mathrm{a}$ & $3.88 \pm 0.23 \mathrm{ab}$ & $4.85 \pm 0.38 \mathrm{~b}$ & $4.03 \pm 0.19 \mathrm{ab}$ & $6.61 \pm 0.35 \mathrm{c}$ & $<0.01$ \\
Cecal Tissue $(\mathrm{g})$ & $0.94 \pm 0.04 \mathrm{a}$ & $1.15 \pm 0.05 \mathrm{abc}$ & $1.24 \pm 0.05 \mathrm{bc}$ & $1.10 \pm 0.04 \mathrm{ab}$ & $1.34 \pm 0.06 \mathrm{c}$ & $<0.01$ \\
Cecal pH & $7.42 \pm 0.09 \mathrm{~b}$ & $6.49 \pm 0.15 \mathrm{a}$ & $6.44 \pm 0.08 \mathrm{a}$ & $6.51 \pm 0.09 \mathrm{a}$ & $6.32 \pm 0.12 \mathrm{a}$ & $<0.01$ \\
\hline
\end{tabular}

Values are means $\pm \mathrm{SE}(n=8)$. Within a row, values not sharing a common letter are significantly different at $P<0.05$

FS2 Resistant maltodextrin, FS2H hydrogenated resistant maltodextrin

mineral absorption rate was positively correlated with cecal pool of SCFA, acetic and propionic acids, and negatively correlated with cecal $\mathrm{pH}$ (Table 7).

\section{Experiment 2}

Food intake and body weight gain were not different among four groups (Table 8). Fecal consistency was normal and neither diarrhea nor soft feces were observed. Apparent mineral absorption rates are shown in Table 9. As a result of two-way ANOVA, all mineral absorptions were significantly influenced by the ingestion of $\mathrm{FS} 2 \mathrm{H}$. Apparent absorptions of $\mathrm{Ca}$ and $\mathrm{Mg}$ had significant interactions with diet and cecectomy, while $\mathrm{Fe}$ and $\mathrm{Zn}$ did not. As a result of multiple comparisons, absorptions of
$\mathrm{Ca}$ and $\mathrm{Mg}$ were significantly increased by the ingestion of FS2H in sham-operated group, while CX group was not.

\section{Discussion}

In this rat balance study, apparent absorption rates of $\mathrm{Ca}$, $\mathrm{Mg}, \mathrm{Fe}$, and $\mathrm{Zn}$ were enhanced by ingestion of FS2 and $\mathrm{HS} 2 \mathrm{H}$ in dose-dependent manner. The enhancements of $\mathrm{Ca}$ and $\mathrm{Mg}$ absorptions were sustained during second period, while $\mathrm{Fe}$ and $\mathrm{Zn}$ absorptions were reduced in the second period with the same tendencies as the first period. Reduced absorption of Fe and $\mathrm{Zn}$ might have resulted from downregulation of the absorptive system. Watanabe et al. 
Table 6 Content and concentration of short-chain fatty acids (SCFA) and organic acids in the cecal content in rats fed test diets for 14 days (Exp. 1)

\begin{tabular}{|c|c|c|c|c|c|c|}
\hline & $\mathrm{Ctr}$ & $1.5 \% \mathrm{FS} 2$ & $3.0 \% \mathrm{FS} 2$ & $1.5 \% \mathrm{FS} 2 \mathrm{H}$ & $3.0 \% \mathrm{FS} 2 \mathrm{H}$ & $P$ \\
\hline \multicolumn{7}{|l|}{ Acetic acid } \\
\hline $\begin{array}{l}\mu \mathrm{mol} / \mathrm{cecum} \\
(\mu \mathrm{mol} / \mathrm{g})\end{array}$ & $\begin{array}{l}69.7 \pm 11.4 \mathrm{a} \\
(30.6 \pm 4.20)\end{array}$ & $\begin{array}{l}98.2 \pm 8.29 a b \\
(25.2 \pm 0.94)\end{array}$ & $\begin{array}{l}121 \pm 11.8 \mathrm{bc} \\
(24.9 \pm 1.81)\end{array}$ & $\begin{aligned} 109 & \pm 3.34 \mathrm{ab} \\
(28.0 & \pm 0.82)\end{aligned}$ & $\begin{array}{l}153 \pm 10.5 \mathrm{c} \\
(24.0 \pm 1.13)\end{array}$ & $\begin{array}{r}<0.01 \\
0.08\end{array}$ \\
\hline \multicolumn{7}{|l|}{ Propionic acid } \\
\hline $\begin{array}{l}\mu \mathrm{mol} / \text { cecum } \\
(\mu \mathrm{mol} / \mathrm{g})\end{array}$ & $\begin{array}{c}26.7 \pm 5.40 \mathrm{a} \\
(11.5 \pm 1.45) \mathrm{a}\end{array}$ & $\begin{array}{c}79.6 \pm 7.56 b c \\
(20.3 \pm 0.97) b\end{array}$ & $\begin{array}{r}96.2 \pm 11.7 b c \\
(19.6 \pm 1.91) b\end{array}$ & $\begin{array}{c}61.7 \pm 7.21 \mathrm{ab} \\
(15.9 \pm 1.77) \mathrm{ab}\end{array}$ & $\begin{array}{c}113 \pm 9.89 \mathrm{c} \\
(17.8 \pm 1.55) \mathrm{ab}\end{array}$ & $\begin{array}{r}<0.01 \\
0.04\end{array}$ \\
\hline \multicolumn{7}{|l|}{$n$-Butyric acid } \\
\hline $\begin{array}{l}\mu \mathrm{mol} / \mathrm{cecum} \\
(\mu \mathrm{mol} / \mathrm{g})\end{array}$ & $\begin{array}{c}23.9 \pm 3.58 \\
(10.4 \pm 0.77)\end{array}$ & $\begin{array}{c}12.5 \pm 4.02 \\
(3.48 \pm 1.16)\end{array}$ & $\begin{array}{c}23.6 \pm 5.72 \\
(4.93 \pm 0.99)\end{array}$ & $\begin{array}{c}23.1 \pm 3.83 \\
(6.01 \pm 1.08)\end{array}$ & $\begin{array}{c}44.2 \pm 11.9 \\
(6.71 \pm 1.63)\end{array}$ & $\begin{array}{l}0.05 \\
0.06\end{array}$ \\
\hline \multicolumn{7}{|l|}{ Total SCFAs ${ }^{\mathrm{a}}$} \\
\hline $\begin{array}{l}\mu \mathrm{mol} / \mathrm{cecum} \\
(\mu \mathrm{mol} / \mathrm{g})\end{array}$ & $\begin{array}{l}120 \pm 19.6 \mathrm{a} \\
(52.6 \pm 5.82)\end{array}$ & $\begin{aligned} 190 & \pm 13.1 \mathrm{ab} \\
(49.0 & \pm 1.20)\end{aligned}$ & $\begin{aligned} 241 & \pm 23.6 b c \\
(49.4 & \pm 3.47)\end{aligned}$ & $\begin{aligned} 193 & \pm 7.96 \mathrm{ab} \\
(49.8 & \pm 2.22)\end{aligned}$ & $\begin{array}{l}310 \pm 19.6 \mathrm{c} \\
(48.5 \pm 1.67)\end{array}$ & $\begin{array}{r}<0.01 \\
0.93\end{array}$ \\
\hline \multicolumn{7}{|l|}{ Lactic acid } \\
\hline $\begin{array}{l}\mu \mathrm{mol} / \text { cecum } \\
(\mu \mathrm{mol} / \mathrm{g})\end{array}$ & $\begin{array}{c}3.57 \pm 2.35 \\
(1.32 \pm 0.69)\end{array}$ & $\begin{array}{c}23.7 \pm 9.49 \\
(6.02 \pm 2.57)\end{array}$ & $\begin{array}{c}17.7 \pm 11.2 \\
(3.27 \pm 1.90)\end{array}$ & $\begin{array}{c}6.74 \pm 4.56 \\
(1.67 \pm 1.13)\end{array}$ & $\begin{array}{c}10.1 \pm 2.83 \\
(1.57 \pm 0.43)\end{array}$ & $\begin{array}{l}0.48 \\
0.31\end{array}$ \\
\hline \multicolumn{7}{|l|}{ Succinic acid } \\
\hline $\begin{array}{l}\mu \mathrm{mol} / \mathrm{cecum} \\
(\mu \mathrm{mol} / \mathrm{g})\end{array}$ & $\begin{array}{c}58.4 \pm 27.4 \mathrm{a} \\
(25.3 \pm 13.0) \mathrm{a}\end{array}$ & $\begin{array}{c}127 \pm 25.7 \mathrm{ab} \\
(33.4 \pm 7.16) \mathrm{ab}\end{array}$ & $\begin{array}{c}153 \pm 20.9 \mathrm{ab} \\
(31.3 \pm 2.92) \mathrm{ab}\end{array}$ & $\begin{array}{r}232 \pm 37.4 b c \\
(59.5 \pm 9.18) b\end{array}$ & $\begin{array}{c}347 \pm 50.7 \mathrm{c} \\
(53.3 \pm 6.88) \mathrm{ab}\end{array}$ & $\begin{array}{r}<0.01 \\
0.01\end{array}$ \\
\hline
\end{tabular}

Values are means $\pm \mathrm{SE}(n=8)$. Within a row, values not sharing a common letter are significantly different at $P<0.05$

FS2 Resistant maltodextrin, FS2H hydrogenated resistant maltodextrin

${ }^{a}$ Total SCFAs includes acetic acid, propionic acid, $n$-butyric acid

Table 7 Correlation between mineral absorption and individual and total SCFA in rats fed test diets for 14 days (Exp. 1)

\begin{tabular}{|c|c|c|c|c|}
\hline & $\mathrm{Ca}$ & $\mathrm{Mg}$ & $\mathrm{Fe}$ & $\mathrm{Zn}$ \\
\hline \multicolumn{5}{|c|}{ Total SCFA } \\
\hline$R$ & $0.41 *$ & $0.48 *$ & $0.54^{*}$ & $0.50 *$ \\
\hline$P$ & 0.02 & $<0.01$ & $<0.01$ & $<0.01$ \\
\hline \multicolumn{5}{|c|}{ Acetic acid } \\
\hline$R$ & $0.41 *$ & $0.45 *$ & $0.55^{*}$ & $0.51 *$ \\
\hline$P$ & 0.02 & $<0.01$ & $<0.01$ & $<0.01$ \\
\hline \multicolumn{5}{|c|}{ Propionic acid } \\
\hline$R$ & $0.47 *$ & $0.50 *$ & $0.45^{*}$ & $0.38^{*}$ \\
\hline$P$ & $<0.01$ & $<0.01$ & $<0.01$ & 0.03 \\
\hline \multicolumn{5}{|c|}{$n$-Butyric acid } \\
\hline$R$ & -0.04 & 0.10 & 0.21 & 0.25 \\
\hline$P$ & 0.821 & 0.586 & 0.238 & 0.161 \\
\hline \multicolumn{5}{|l|}{$\mathrm{pH}$} \\
\hline$R$ & $-0.64 *$ & $-0.60 *$ & $-0.61 *$ & $-0.62^{*}$ \\
\hline$P$ & $<0.01$ & $<0.01$ & $<0.01$ & $<0.01$ \\
\hline
\end{tabular}

* Significant correlation $(P<0.05)$

[19] reported the same phenomenon with rat fed on phosphorylated guar gum hydrolysate.

Iron is predominantly stored in the liver. We therefore measured the iron content in the liver. Since both $\mathrm{Fe}$ content in the liver and apparent $\mathrm{Fe}$ absorption were dose-
Table 8 Effect of caecectomy and experimental diets on food intake and body weight gain in rats fed test diets for 7 days (Exp. 2)

\begin{tabular}{lll}
\hline Diet group & $\begin{array}{l}\text { Food intake } \\
(\mathrm{g} / 7 \text { days })\end{array}$ & $\begin{array}{l}\text { Body weight gain } \\
(\mathrm{g} / 7 \text { days })\end{array}$ \\
\hline Sham-Ctr & $111.0 \pm 1.00$ & $37.3 \pm 1.29$ \\
Sham-FS2H & $110.5 \pm 0.76$ & $39.5 \pm 1.53$ \\
CX-Ctr & $112.8 \pm 0.89$ & $37.7 \pm 2.52$ \\
CX-FS2H & $113.8 \pm 0.72$ & $34.1 \pm 0.64$ \\
$P$ values by ANOVA & & \\
$\quad$ Diet & 0.775 & 0.641 \\
Caecectomy & 0.010 & 0.101 \\
$\quad$ Diet $\times$ caecectomy & 0.409 & 0.056
\end{tabular}

Values are mean $\pm \mathrm{SE}(n=8)$

FS2 Resistant maltodextrin, FS2H hydrogenated resistant maltodextrin

dependently increased, it is indicated that ingestion of resistant maltodextrin enhanced $\mathrm{Fe}$ absorption and part of $\mathrm{Fe}$ absorbed was stored in the liver. Meanwhile it is possible that enhanced calcium absorption cause renal calculus because of deposition of calcium in the kidney. In this study, ingestion of resistant maltodextrin did not change calcium content in the kidney; thus, resistant maltodextrin has no risk of causing renal calculus. 
Table 9 Effect of caecectomy and test diet on mineral absorption in rats fed test diets for 7 days (Exp. 2)

\begin{tabular}{lllll}
\hline & $\mathrm{Ca}$ & $\mathrm{Mg}$ & $\mathrm{Fe}$ & $\mathrm{Zn}$ \\
\hline Sham-Ctr & $70.4 \pm 4.58 \mathrm{a}$ & $66.4 \pm 2.62 \mathrm{a}$ & $33.0 \pm 4.94$ & $14.2 \pm 6.72$ \\
Sham-FS2H & $87.1 \pm 1.78 \mathrm{a}$ & $85.7 \pm 1.38 \mathrm{~b}$ & $56.9 \pm 5.03$ & $38.0 \pm 5.76$ \\
CX-Ctr & $77.3 \pm 1.39 \mathrm{ab}$ & $61.4 \pm 2.33 \mathrm{a}$ & $43.7 \pm 2.53$ & $26.9 \pm 2.97$ \\
CX-FS2H & $81.1 \pm 1.23 \mathrm{~b}$ & $66.9 \pm 1.30 \mathrm{a}$ & $52.4 \pm 1.96$ & $33.5 \pm 4.69$ \\
$P$ values by ANOVA & & & 0.001 & 0.020 \\
Diet & 0.003 & $<0.001$ & 0.496 & 0.506 \\
Caecectomy & 0.881 & $<0.001$ & 0.101 & 0.173 \\
Diet $\times$ caecectomy & 0.046 & 0.003 & & \\
\hline
\end{tabular}

Values are mean $\pm \mathrm{SE}(n=8)$. Within a column, values not sharing a common letter are significantly different at $P<0.05$

FS2 Resistant maltodextrin, FS2H hydrogenated resistant maltodextrin

Enhanced calcium and magnesium absorption by soluble dietary fiber and indigestible oligosaccharides is related to SCFA production by cecal fermentation [5, 20]. We observed the positive relationships between apparent mineral absorption and SCFA. A previous study showed that a half of resistant maltodextrin reaching the cecum is fermented by intestinal bacteria, and increases cecal weight and cecal SCFA content [17]. In the present study, we found dose-dependent cecal expansion with increasing SCFA pool by ingestion of resistant maltodextrin. Enlarged cecal tissue causes expansion of absorption area and leads to promotion of mineral absorption. It has been reported that one factor for increase in calcium absorption is expanded luminal area with increasing cecal epithelial cells [8]. Luminal SCFA is known to promote epithelial cell proliferation [12]. Additionally, acetic and propionic acids were increased by the ingestion of resistant maltodextrin, and positively correlated with mineral absorption. Trinidad et al. [14] reported that acetate and propionate infused into the rectum enhanced calcium absorption. These results suggest that acetate and propionate produced from resistant maltodextrin are involved in the increasing mineral absorption. Acetate/propionate ration was higher in control group than four other groups. It is known that production of propionate tends to be enhanced by ingestion of resistant maltodextrin, which support the result of this study.

We examined influence of cecectomy on changes in apparent mineral absorption. FS2H is used in this experiment since there was no difference between FS2 and FS2H in the effect of mineral absorption in experiment 1 . The absorptions of $\mathrm{Ca}$ and $\mathrm{Mg}$ were increased by $\mathrm{FS} 2 \mathrm{H}$ ingestion in Sham rats, but not in CX rats. Similar result was observed in the experiment with rats fed guar gum hydrolysate $(\mathrm{GGH})$, indicating that promotion of $\mathrm{Ca}$ and $\mathrm{Mg}$ absorption totally depends on the cecum [5]. Enhancement of $\mathrm{Ca}$ and $\mathrm{Mg}$ absorption by resistant maltodextrin is concerned with the cecum, which is based on the mechanism described above. In contrast to $\mathrm{Ca}$ and $\mathrm{Mg}$ absorption, results of two-way ANOVA analyses revealed that apparent absorptions of $\mathrm{Fe}$ and $\mathrm{Zn}$ were influenced by diet with no interaction between diet and cecectomy, showing resistant maltodextrin is still effective in the cecectomized rats. Possibly, gastrointestinal tracts other than the cecum contribute to the enhancement of $\mathrm{Fe}$ and $\mathrm{Zn}$ absorption. Generally, Fe and $\mathrm{Zn}$ are mainly absorbed from upper part of the small intestine, and it has been reported that $\mathrm{Zn}$ solubility in the cecum do not correlate with $\mathrm{Zn}$ absorption [4]. Not only cecal fermentation, but also other mechanisms may be associated with the promotion of $\mathrm{Fe}$ and $\mathrm{Zn}$ absorption by resistant maltodextrin. Although effect of resistant maltodextrin on gastrointestinal tracts other than the cecum is not examined in this study, direct enhancement mechanism on the upper part of the small intestine may contribute to the additional effect on $\mathrm{Fe}$ and $\mathrm{Zn}$ absorption. Effect of resistant maltodextrin on mineral absorption in the upper part of the small intestine should be examined in future.

Additionally, there are possibilities that mineral absorptions are also enhanced in human since resistant maltodextrin is reported to be fermented by intestinal bacteria in human. We have also conducted a preliminary human study with a small number of subjects and the favorable effect on $\mathrm{Fe}$ absorption was observed. We would like to study further on effectiveness of long-term ingestion of resistant maltodextrin on iron-deficiency anemia as well.

\section{Conclusion}

We investigated effects of resistant maltodextrin and hydrogenated resistant maltodextrin on apparent absorptions of $\mathrm{Ca}, \mathrm{Mg}, \mathrm{Fe}$ and $\mathrm{Zn}$ in rats by balance study and reached the conclusion as follows. (1) Ingestion of resistant maltodextrin and hydrogenated resistant maltodextrin dosedependently increases apparent mineral absorption. (2) Mechanism of $\mathrm{Ca}$ and $\mathrm{Mg}$ absorption by resistant 
maltodextrin is dependent on cecal fermentation; however, gastrointestinal tract other than the cecum also contributes to the enhancement for $\mathrm{Fe}$ and $\mathrm{Zn}$ absorption.

Open Access This article is distributed under the terms of the Creative Commons Attribution Noncommercial License which permits any noncommercial use, distribution, and reproduction in any medium, provided the original author(s) and source are credited.

\section{References}

1. Brommage R, Binacua C, Antille S, Carrié AL (1993) Intestinal calcium absorption in rats is stimulated by dietary lactulose and other resistant sugars. J Nutr 123:2186-2194

2. Fujiwara K, Matsuoka A (1995) Improvement of glucose tolerance by low-viscosity, water-soluble dietary fiber, indigestible dextrin. Jpn J Nutr Diet 53:361-368

3. Gordon DT, Okuma K (2002) Determination of total dietary fiber in selected foods containing resistant maltodextrin by enzymaticgravimetric method and liquid chromatography: collaborative study. J AOAC Int 85:435-444

4. Hara H, Konishi A, Kasai T (1999) Effect of water soluble dietary fiber on zinc absorption in rats. J Jpn Assoc Dietary Fiber Res 3:73-78

5. Hara H, Nagata M, Ohta A, Kasai T (1996) Increases in calcium absorption with ingestion of soluble dietary fiber, guar-gum hydrolysate, depend on the caecum in partially nephrectomized and normal rats. Br J Nutr 76:773-784

6. Hayashi K, Hara H, Asvarujanon P, Aoyama Y, Luangpituksa P (2001) Ingestion of insoluble dietary fibre increased zinc and iron absorption and restored growth rate and zinc absorption suppressed by dietary phytate in rats. Br J Nutr 86:443-451

7. Kishimoto Y, Oga H, Hayashi N, Yamada T, Tagami H (2007) Suppressive effect of resistant maltodextrin on postprandial blood triglyceride elevation. Eur J Nutr 46:133-138

8. Mineo H, Amano M, Minamida K, Chiji H, Shigematsu N, Fomita F, Hara H (2006) Two-week feeding of difructose anhydride III enhances calcium absorptive activity with epithelial cell proliferation in insolated rat cecal mucosa. Nutrition 22:312-320
9. Nomura M, Ohashi M, Nishigawa T, Kubota M, Ohkuma K, Nakajima Y, Abe H (1992) Effects of dietary fibers on the diffusion of glucose and metal ions through cellulose membrane. J Jpn Soc Clin Nutr 13:141-147

10. Ohkuma K, Matsuda I, Katta Y, Hanno Y (1990) Pyrolysis of starch and its digestibility by enzymes-characterization of indigestible dextrin. J Jpn Soc Starch Sci 37:107-114

11. Okuma K, Matsuda I (2003) Production of indigestible dextrin from pyrodextrin. J Appl Glycosci 50:389-394

12. Roediger WE, Rae DA (1982) Trophic effect of short chain fatty acids on mucosal handling of ions by the defunctioned colon. Br J Surg 69:23-25

13. Satouchi M, Wakabayashi S, Ohkuma K, Fujiwara K, Matsuoka A (1993) Effects of indigestible dextrin on bowel movements. Jpn J Nutr Diet 51:31-37

14. Trinidad TP, Wolever TMS, Thompson LU (1996) Effect of acetate and propionate on calcium absorption from the rectum and distal colon of human. Am J Clin Nutr 63:574-578

15. Tsuji K, Gordon DT (1998) Energy value of a mixed glycosidic linked dextrin determined in rats. J Agric Food Chem 46:22532259

16. van den Heuvel EG, Muys T, van Dokkum W, Schaafsma G (1999) Oligofructose stimulates calcium absorption in adolescents. Am J Clin Nutr 69:544-548

17. Wakabayashi S, Satouchi M, Nogami Y, Ohkuma K, Matsuoka A (1991) Effect of indigestible dextrin on cholesterol metabolism in rat. J Jpn Soc Nutr Food Sci 44:471-478

18. Wakabayashi S, Satouchi M, Ueda Y, Ohkuma K (1992) Acute toxicology and mutagenicity studies of indigestible dextrin and its effect on bowel movement of the rat. J Food Hyg Soc Jpn 33:557-562

19. Watanabe O, Hara H, Aoyama Y, Kasai T (2000) Increased intestinal calcium absorption from the ingestion of a phosphorylated guar gum hydrolysate independent of cecal fermentation in rats. Biosci Biotechnol Biochem 64:613-616

20. Yanahira S, Morita M, Aoe S, Suguri T, Takada Y, Miura S, Nakajima I (1997) Effect of lactitol-oligosaccharides on calcium and magnesium absorption in rats. J Nutr Sci Vitaminol 43:123132 